\title{
Parental Education and Social and Cultural Capital in Academic Achievement
}

\author{
Reza Pishghadam (Corresponding author) \\ English Department, Ferdowsi University of Mashhad \\ PO box 9177948974, Park Square, Ferdowsi University, Mashhad, Iran \\ Tel: 98-915-307-3063 E-mail: rpishghadam@yahoo.com
}

Reza Zabihi

Department of English Language and Literature, Ferdowsi University of Mashhad

Mashhad, 91779-48883, Iran

E-mail: zabihi@hotmail.com

Received: February 3, 2011 Accepted: February 23, 2011 doi:10.5539/ijel.v1n2p50

\begin{abstract}
The relationship between social and cultural capital and academic achievement was explored in this study by administering the Social and Cultural Capital Questionnaire (SCCQ) to 320 undergraduate students majoring in English language, and correlating the respective subscales with the learners' university GPA. All five factors of SCCQ were found to be correlated significantly with the learners' GPA. Moreover, having conducted the regression analysis, the researchers found out that literacy and cultural competence were predictive of higher GPA. The researchers then entered parents' educational levels into the regression model. The results of this analysis indicated that, together with literacy, mother's educational level predicted $23 \%$ of the variances in learners' GPA. However, father's educational level was not a good predictor of academic achievement. The implications of the results were discussed within a foreign language context and suggestions were made for future research.
\end{abstract}

Keywords: Academic achievement, Parental education, University GPA, Social and cultural capital, Foreign language context

\section{Introduction}

One of the greatest concerns of educational sociology has been to see whether students' socio-economic backgrounds would bear any relationship to the measures of achievement. The concepts of cultural and social capital are increasingly used to explain differential academic achievement in developed as well as developing nations (e.g., Eng, 2009; Israel \& Beaulieu, 2004; Merenluoto, 2009; Sandefur, Meier, \& Hernandez, 1999).

However, it seems that, the operationalisation of these concepts has not yet received substantial attention. It was not until recently that researchers have set about designing scales for the measurement of social and cultural capital. The first attempts were made by Pishghadam, Noghani, and Zabihi (2011) who designed and validated a 42-item questionnaire of social and cultural capital, and by Khodadady and Zabihi (In press) who have validated a revised version of the same scale comprising 35 items.

There is an accord among researchers, in the area of education, on the necessity of recognizing the structure of relations among social and educational institutions by examining how individuals' different social and cultural experiences affect their educational outcomes (Eng, 2009; Kim \& Schneider, 2005; Prado, 2009; Schlee, Mullis, \& Shriner, 2009; Tramonte \& Willms, 2010).

Research in the domain of general education has shown that there is a high association between social and cultural capital and academic achievement (De Graaf, De Graaf, \& Kraaykamp, 2000; Kim \& Schneider, 2005; Prado, 2009). It means that those who have more access to these two types of capital are more successful in educational attainment. To our best knowledge, no study has been done to date to explore the relationship between social and cultural capital and university EFL students' academic achievement. Thus in this paper, we have examined the relationship between social and cultural capital and university GPA among a group of EFL learners. The researchers have also attempted to predict academic achievement from the combination of social and cultural capital and parental education.

\section{Theoretical framework}

In the following paragraphs, we will review the notions related to cultural and social capital and empirical findings pertaining to these issues and their applications both in general education and language learning. 
Cultural capital refers to individuals' access to different cultural goods such as, Internet, computers, pictures, paintings, books, and dictionaries. There is growing evidence that cultural capital tends to be a crucial factor in students' progress in different areas of academic achievement such as school grades (DiMaggio, 1982; Khodadady \& Zabihi, In press), educational attainment (De Graaf, De Graaf, \& Kraaykamp, 2000; Merenluoto, 2009; Nakhaie \& Curtis, 1998), and student persistence (Sandefur, Meier, \& Hernandez, 1999; Wells, 2008).

Along with cultural capital, social capital has also been studied widely in various fields. It was first introduced into the literature by Bourdieu (1986, p. 248) who defined it as "the aggregate of the actual or potential resources which are linked to possession of a durable network of more or less institutionalized relationships of mutual acquaintance and recognition.” Bourdieu (1986) and Coleman (1988) have approached social capital from sociological and educational perspectives, respectively. The arguments put forward by Bourdieu and Coleman had germinated many research studies to examine the relation of social capital to other variables such as academic achievement. Social capital, thus, has proved to be an important predictor of academic success (e.g., Eng, 2009; Israel \& Beaulieu, 2004; Israel, Beaulieu, \& Hartless, 2001). In their attempts to find an answer to the question "For whom does the school bell toll?" (p. 127), Beaulieu, Israel, Hartless, and Dyk (2001) conducted a study to examine the role of family, school, and community on students' educational achievement. They concluded that " $\ldots$ the school bell tolls for those students who have access to, and who actively engage in caring and guiding environments not only in the home, but also with other adults located with the school and broader community settings" (p. 127).

There has been a large body of research investigating the role of social and cultural capital in students' academic success, in general, and in their academic achievement and attainment, in particular. Smith, Beaulieu, and Israel (1992), for example, explored the effect of family socioeconomic status on the probability of high school students' dropping out of school. They found that higher levels of Socioeconomic Status (SES) were negatively associated with students' dropping out of school. Another study conducted by Sandefur, Meier, and Hernandez (1999) examined the effect of social capital on the probability of students' graduation and entering a post-secondary education. They concluded that social capital had a significant impact on high school graduation and college attendance. Israel, Beaulieu, and Hartless (2001) did a study to investigate the effect of social capital on promoting educational achievement among public school students. They showed that social capital (both family and community) influenced high school students' educational achievement. Conversely, Crosnoe (2004) observed that students' distant relationships with parents would result in declining their academic achievement, a finding which highlighted the importance of the interplay of family and school as main sources of providing social capital. Different dimensions of social capital (e.g. individual and family characteristics, school experience, and participation in extracurricular activities) were taken into consideration by Israel and Beaulieu (2004) to see if they had any effect on students' academic achievement and their staying in school. The results of their study confirmed the hypothesis that families, schools, and communities play important roles in students' academic success and, as a result, their staying in school. Having refined the social capital theory with the concept of alignment between parents' and adolescents' goals and actions, Kim and Schneider (2005) sought to find out the effect of social capital in the transition to postsecondary education. The results indicated that this conception of social capital increased students' chances of attending a postsecondary institution in the year after high school graduation. In an attempt to examine the relationship between social capital and students' scores on mathematics, Bassani (2006) surveyed students of three countries from three different continents. Significant associations were found between students' social capital and their math scores. Moreover, Robert (2003) conducted a research to see the effect of social capital on students' reading performance. He focused on three indicators of social capital as independent variables: parent-child relations in the family, teacher/school-pupil relations, and parent-school relations. The results showed that parental academic interest and teacher-student relationship were significantly related to students' reading performance. In another study, Wells (2008) defined student persistence as enrollment at any postsecondary educational institution, and found that both cultural and social capital had positive associations with student persistence. In a similar vein, Eng (2009) focused on several dimensions of social capital (e.g. parents' academic involvement, parents' educational aspirations, family demands, parent-teacher relationship, and parent-relative relationship), and found that both family and school social capital were significantly associated with students' academic achievement. On the other hand, Merenluoto (2009) worked on several variables of cultural capital (e.g. father's education level, mother's education level, previous school success, and the importance placed on cultural activities) and sought to find out the effect of these variables on graduate students' academic success. It was revealed that cultural capital had a positive effect on students' success and attainment in higher education. In a recent study, Khodadady and Zabihi (In press) investigated the relationship between social and cultural capital and Iranian students' school achievement as measured by learners' self-reports on diploma GPA. The results of their study indicated that only social capital showed a significant relationship with the GPA. Similarly, among the ten factors studied, parent-school encouragement and facility, parental consultation, family relationship, and family support, correlated 
significantly with the diploma GPA. In their attempts to explore the effect of EFL learners' social status on their foreign language achievement, Pishghadam, Noghani, and Zabihi (2011) designed a questionnaire of social and cultural capital, and administered it to undergraduate university students. The results indicated that among the five subscales of Social competence, Social Solidarity, Literacy, Cultural competence, and Extraversion, cultural competence was the best predictor of the listening skill, whereas speaking, reading, writing, and grammar were mostly predicted by learners' literacy, a subcomponent of cultural capital.

\subsection{Purpose of the present study}

As mentioned earlier, a considerable amount of research has focused on the relationship between cultural capital and academic achievement (e.g., De Graaf, De Graaf, \& Kraaykamp, 2000; DiMaggio, 1982; Merenluoto, 2009), and on the association between social capital and academic achievement (e.g., Eng, 2009; Israel \& Beaulieu, 2004; Israel, Beaulieu, \& Hartless, 2001; Khodadady \& Zabihi, in press). This study pursues the role of students' social and cultural capital in their academic achievement. It also seeks to investigate the role of parental education levels in students' achievement. Therefore, this research is conducted to find out answers to the following questions:

Q1: Is there a significant relationship between students' social capital and their academic achievement?

Q2: Is there a significant relationship between students' cultural capital and their academic achievement?

Q3: Do parents' educational levels predict EFL learners' university academic achievement?

Q4: What are the predictors of academic achievement in social and cultural capital?

\section{Method}

\subsection{Participants}

A sample of 320 people participated in this study, comprised of 247 females (77\%) and 73 males (23\%) between the ages of 18 and $37(\mathrm{M}=21.78, \mathrm{SD}=3.12)$ in Mashhad, a city in north-eastern Iran. All of the participants were undergraduate university students attending three universities in Iran, majoring in Teaching English as a Foreign Language, English Language and Literature, and English Translation.

\subsection{Instruments}

\subsubsection{The Social and Cultural Capital Questionnaire (SCCQ)}

Developed by Pishghadam, Noghani, and Zabihi (2011), the questionnaire was designed to measure students' social and cultural capital. The results of Exploratory Factor Analysis (EFA) based on the performance of undergraduate university students on this questionnaire yielded a five-factor solution of social competence, social solidarity, literacy, cultural competence, and extraversion. It comprises 42 items that are scored on a Likert scale of 5-points (see Appendix). For the scoring of the SCCQ we simply assign values 1, 2, 3, 4, and 5 to options strongly disagree, disagree, undecided, agree, and strongly agree, respectively. The reliability estimates for the five underlying factors of SCCQ are as follows: social competence, $r=.89$; social solidarity, $r=.75$; literacy, $r=.68$; cultural competence, $\mathrm{r}=.65$; extraversion, $\mathrm{r}=.51$. The reliability of the whole items is 0.88 . In this study, the reliability estimates for the five subscales were as follows: social competence, $r=.87$; social solidarity, $r=.77$; literacy, $\mathrm{r}=.63$; cultural competence, $\mathrm{r}=.65$; extraversion, $\mathrm{r}=.47$. Moreover, the reliability of the whole items (i.e. 42 items) estimated by Cronbach Alpha was .90 .

\subsection{Procedures}

The SCCQ was distributed among 320 EFL learners. The administration phase occurred during class hours by prior arrangement with the instructors. The instruments were administered to students in one session and they were asked to fill them out under standard conditions. Students were asked not to mention their names on the questionnaires; rather, the questionnaires were coded numerically. Further information regarding learners' parental education levels and their families' incomes were also obtained by providing learners with a separate section on the questionnaire. On average, the responding duration was 17 minutes.

The data gathered from the questionnaire was analyzed by utilizing SPSS version 16.0. To examine the normality of the distribution, descriptive statistics was employed. To investigate the relation of SCCQ subscales to learners' academic achievement, Pearson product-moment correlation was applied to the data. To find out to what extent SCCQ factors might have predictive power in EFL learners' academic achievement, regression analysis was run.

\section{Results}

4.1 Descriptive statistics

Table 1 summarizes the descriptive results of the SCCQ and learners' GPA. 


\subsection{The results of correlation between students' scores on SCCQ subscales and their academic achievement (GPA)}

To explore whether there is any significant correlation between the learners' social and cultural capital and English achievement (GPA), Pearson product-moment correlation was employed. The results indicated that there are significant correlations between learners' GPA and all subscales on the SCCQ: social competence $(r=0.177$, $\mathrm{p}<0.01)$, social solidarity $(\mathrm{r}=0.211, \mathrm{p}<0.01)$, literacy $(\mathrm{r}=0.365, \mathrm{p}<0.01)$, cultural competence $(\mathrm{r}=0.298, \mathrm{p}$ $<0.01)$, and extraversion $(\mathrm{r}=0.142, \mathrm{p}<0.05)$. Moreover, a significant correlation was found between GPA and learners' total score on SCCQ $(r=0.298, \mathrm{p}<0.01)$ (see Table 2).

\subsection{Prediction of academic achievement by SCCQ factors}

To further analyze the data, the researchers conducted the regression analysis with a Stepwise method. The results reveal which variables are important in predicting learners' academic achievement. Learners' GPA explained $14 \%$ of the total variance, (Adjusted $\mathrm{R}^{2}=0.14, \mathrm{p}<.05$ ) using a combination of literacy and cultural competence. Literacy was the best predictor of higher GPAs (Adjusted $\mathrm{R}^{2}=0.13, \mathrm{p}<.05$ ), indicating that high scorers in literacy were more successful in the academic setting. Table 3 presents the results for learners' GPA being regressed on the variables of interest in this study (SCCQ subscales).

4.4 Prediction of academic achievement by SCCQ factors and demographic information obtained from the participants

Researchers also examined the effect of social and cultural capital subscales together with parents' educational levels on learners' academic achievement. This time learners' GPA explained $23 \%$ of the total variance, (Adjusted $\mathrm{R}^{2}=0.23, \mathrm{p}<.05$ ) using a combination of literacy and mother's educational level. Table 4 presents the results for learners' GPA being regressed on the variables of interest in this study (SCCQ subscales and parent's educational levels).

\section{Discussion}

In this study, we have used our previously-designed-and-validated questionnaire of social and cultural capital (Pishghadam, Noghani, \& Zabihi, 2011) in order to examine the role of its underlying factors (social competence, social solidarity, literacy, cultural competence, and extraversion) in university EFL learners' academic achievement in the context of Iran. Analyses of these data have shown that the variables of primary interest, i.e. social capital, cultural capital, and parents' educational levels, have significant and important influences on achievement. For example, a combination of literacy and cultural competence was a good predictor of learners' GPA. Having high levels of literacy and cultural competence was best predictor of higher levels of academic achievement. Cultural competence proved to be a significant predictor, though only minimally, of academic achievement in the EFL context studied. However, literacy alone was found to be a highly significant factor in explaining academic achievement.

Literacy is regarded as a social practice (McKay \& Hornberger, 1996) and it is not only achieved by individuals, but also it can be obtained in schools, in families (family literacy), in the workplace, etc. (Kern, 2000). Since foreign language learners might come from different cultural backgrounds, it is recommended that foreign language teachers become aware of the different kinds and levels of literacy that learners bring with them to the language classroom. Therefore, in order to go beyond literacy, material developers should begin to integrate and embed into the curriculum the literacies of different social classes, including those of minorities. For this purpose, they should first understand and be sensitive to the nuances in the language and communication patterns of different social classes.

Moreover, parents should encourage their children to spend more time reading extensive foreign language learning materials, rather than working intensively on academic materials. Extensive reading is an approach to reading which resembles that of native speakers reading in their mother tongue: It is reading very large amounts of material in the target language (Helgesen, 2005) and longer texts consistently over a long period of time to get a general meaning which can happen during class time or at home (Hedge, 2000, p. 202). So it is suggested that lesson planning practitioners include extensive reading materials in reading programs.

When researchers entered parents' educational levels into the regression model, it was revealed that only mother's educational level was significantly and positively predictive of learners' university GPA. Together with literacy, mothers' educational levels explained near a quarter of the variances in EFL learners' university GPA. This finding is similar to those obtained in other studies which have found that parents' education has positive effects on children's achievement (Acharya \& Joshi, 2009; Davis-Kean, 2005; Eng, 2009; Merenluoto, 2009). Parents of higher educational levels have greater success in providing their children with the skills they need to be successful in an academic setting. As Acharya and Joshi (2009) point out, "Educated parents transfer the value of education to their children which in turn affect the aspiration level and achievement of the child (p. 77)." Interestingly, however, father's educational level bore no relationship with the university achievement of 
participants in the present study and thus calls for further research to find out why father's education does not bear any significant relationship on achievement in Iran, while mother's education is so important in learners' academic achievement. One reason may be that in the context of Iran it is fathers' responsibility to work outside home, whereas mothers are traditionally supposed to work at home and take care of children. The crucial role of mothers is clarified in Milne, Myers, Rosenthal, and Ginsburg`s study (1986) who have found that mothers' working outside home and their having little time to spend with children have negative effects on children's school achievement. The results of this research and earlier studies supported the notion that mother's education is one of the most important factors influencing learners' achievement levels. It is suggested, therefore, that mothers spend more time with their children at home, while continuously nurturing them with practices such as reading to them in English, watching English cartoons or movies, and holding discussions with them on how they can best handle another language may be useful.

In the end, it must be emphasized that students from richer socio-economic and cultural home backgrounds seemingly tend to acquire higher achievement levels in English, but without a similar focus on parent education, especially mothers' education, it will not be enough to reach one's full potential. It is therefore vital to study the ways in which parents, as the child's first teachers, can be enabled to foster the child's language development through alignment of home-school literacy practices. To achieve this end, one must first explore and understand learners' home literacy practices. It is only then that English teachers can help learners reach their full potential in academic development.

\section{References}

Acharya, N., \& Joshi, S. (2009). Influence of parents' education on achievement motivation of adolescents. Indian Journal of Social Science Researches, 6(1), 72-79.

Bassani, C. (2006). A test of social capital theory outside of the American context: Family and school social capital and youths' math scores in Canada, Japan, and the United States. International Journal of Educational Research, 45(6), 380-403. doi:10.1016/j.ijer.2007.03.001, http://dx.doi.org/10.1016/j.ijer.2007.03.001

Beaulieu, L. J., Israel, G. D., Hartless, G., \& Dyk, P. (2001). For whom does the school bell toll? multi-contextual presence of social capital and student educational achievement. Journal of Socio-Economics, 30, 121-127. doi:10.1016/S1053-5357(00)00090-1, http://dx.doi.org/10.1016/S1053-5357(00)00090-1

Bourdieu, P. (1986). The forms of capital. In J.G. Richardson (Ed.), Handbook for theory and research for the sociology of education. (pp. 241-258). New York: Greenwood Press.

Coleman, J. S. (1988). Social capital in the creation of human capital. American Journal of Sociology, 94, S95-S120. doi:10.1086/228943, http://dx.doi.org/10.1086/228943

Crosnoe, R. (2004). Social capital and the interplay of families and schools. Journal of Marriage and Family, 66, 267-280. doi:10.1111/j.1741-3737.2004.00019.x, http://dx.doi.org/10.1111/j.1741-3737.2004.00019.x

Davis-Kean, P. E. (2005). The influence of parent education and family income on child achievement: The indirect role of parental expectations and the home environment. Journal of Family Psychology, 19(2), 294-304. doi:10.1037/0893-3200.19.2.294, http://dx.doi.org/10.1037/0893-3200.19.2.294

De Graaf, N.D., De Graaf, P.M., \& Kraaykamp, G. (2000). Parental cultural capital and educational attainment in the Netherlands: A refinement of the cultural capital perspective. Sociology of Education, 73(2), 92-111. doi:10.2307/2673239, http://dx.doi.org/10.2307/2673239

DiMaggio, P. (1982). Cultural capital and school success: The impact of status culture participation on the grades of U.S. high school students. American Sociological Review, 47, 189-201. doi:10.2307/2094962, http://dx.doi.org/10.2307/2094962

Eng, S. (2009). Social capital and academic achievement among children in Cambodia: A close look at family. Ph.D. thesis, Texas Tech University.

Hedge, T. (2000). Teaching and learning in the language classroom. Oxford: Oxford University Press.

Helgesen, M. (2005). Extensive reading reports - Different intelligences, different levels of processing. Asian EFL Journal, 7(3), 25-33. [Online] Available: http://www.asian-efl-journal.com/September_05_mh.php (May 21, 2010).

Israel, G. D., \& Beaulieu, L. J. (2004). Investing in communities: Social capital's role in keeping youth in school. Journal of the Community Development Society, 34, 35-57. doi:10.1080/15575330409490111, http://dx.doi.org/10.1080/15575330409490111

Israel, G. D., Beaulieu, L. J., \& Hartless, G. (2001). The influence of family and community social capital on educational achievement. Rural Sociology, 66, 43-68. doi:10.1111/j.1549-0831.2001.tb00054.x, http://dx.doi.org/10.1111/j.1549-0831.2001.tb00054.x 
Kern, R. (2000). Literacy and language teaching. Oxford: Oxford University Press.

Khodadady, E., \& Zabihi, R. (In press). Social and cultural capital: Underlying factors and their relationship with the school achievement of Iranian university students. International Education Studies.

Kim, D. H., \& Schneider, B. (2005). Social capital in action: Alignment of parental support in adolescents' transition to postsecondary education. Social Forces, 84, 1181-1206. doi:10.1353/sof.2006.0012, http://dx.doi.org/10.1353/sof.2006.0012

McKay, S.L. (1996). Literacy and literacies. In S. L. McKay, \& N. H. Hornberger (Eds.), Sociolinguistics and language teaching. (pp. 421-445). Cambridge: Cambridge University Press.

Merenluoto, S. (2009). The connection of cultural capital with success in master's degree programs in Finnish higher education. Research on Finnish Society, 2, 29-38.

Milne, A. M., Myers, D. E., Rosenthal, A. S., \& Ginsburg, A. (1986). Single parents, working mothers, and the educational achievement of school children. Sociology of Education, 59, 125-139. doi:10.2307/2112335, http://dx.doi.org/10.2307/2112335

Nakhaie, M.R., \& Curtis, J. (1998). Effects of class positions of parents on educational attainment of daughters and sons. The Canadian Review of Sociology and Anthropology, 35(4), 483-515. doi:10.1111/j.1755-618X.1998.tb00733.x, http://dx.doi.org/10.1111/j.1755-618X.1998.tb00733.x

Pishghadam, R. Noghani, M. \& Zabihi, R. (2011). The construct validation of a questionnaire of social and cultural capital, and its application to foreign language learning. Unpublished manuscript, Department of English Language and Literature, Ferdowsi University, Mashhad, Iran.

Prado, J. M. (2009). Comparing educational trajectories of two Chinese students and one Latina student, a social capital approach. The High School Journal, 92, 14-27. doi:10.1353/hsj.0.0015, http://dx.doi.org/10.1353/hsj.0.0015

Robert, P. (2003). Social capital and educational achievement: The PISA 2000 results. Budapest: Hungarian Ministry of Education and the Center for Educational Research and Innovation, OECD.

Sandefur, G., Meier, A., \& Hernandez, P. (1999). Families, social capital and educational continuation. CDE Working Paper No. 99-19: Center for Demography and Ecology. Madison, WI: University of Wisconsin-Madison.

Schlee, B. M., Mullis, A. K., \& Shriner, M. (2009). Parents social and resource capital: Predictors of academic achievement during early childhood. Children and Youth Services Review, 31, 227-234. doi:10.1016/j.childyouth.2008.07.014, http://dx.doi.org/10.1016/j.childyouth.2008.07.014

Smith, M. H., Beaulieu, L. J., \& Israel, G. D. (1992). Effects of human capital and social capital on dropping out of high school in the South. Journal of Research in Rural Education, 8, 75-87.

Tramonte, L., \& Willms, J. D. (2010). Cultural capital and its effects on education outcomes. Economics of Education Review, 29, 200-213. doi:10.1016/j.econedurev.2009.06.003, http://dx.doi.org/10.1016/j.econedurev.2009.06.003

Wells, R. (2008). The effects of social and cultural capital on student persistence. Community College Review, 36, 25-46. doi:10.1177/0091552108319604, http://dx.doi.org/10.1177/0091552108319604

Table 1. Means and standard deviations of learners' scores on SCCQ subscales and GPA

\begin{tabular}{|l|c|c|c|c|c|}
\hline & $\mathrm{N}$ & Min & Max & Mean & SD \\
\hline Social Competence & 320 & 0 & 75 & 43.06 & 10.96 \\
\hline Social Solidarity & 320 & 0 & 55 & 38.36 & 8.21 \\
\hline Literacy & 320 & 0 & 38 & 21.32 & 4.84 \\
\hline Cultural Competence & 320 & 0 & 35 & 22.86 & 5.05 \\
\hline Extraversion & 320 & 0 & 15 & 9.40 & 3.01 \\
\hline Total SCCQ & 320 & 0 & 210 & 135.0 & 25.91 \\
\hline GPA & 272 & 12.00 & 19.90 & 16.50 & 1.67 \\
\hline
\end{tabular}


Table 2. Correlations between SCCQ factors and EFL learners' GPA

\begin{tabular}{|l|l|}
\hline & GPA \\
\hline Social Competence & $0.177^{* *}$ \\
\hline Social Solidarity & $0.211^{* *}$ \\
\hline Literacy & $0.365^{* *}$ \\
\hline Cultural Competence & $0.298^{* *}$ \\
\hline Extraversion & $0.142^{*}$ \\
\hline Total SCCQ & $0.298^{* *}$ \\
\hline
\end{tabular}

** Shows the existence of significant relationship at the level of 0.01

* Shows the existence of significant relationship at the level of 0.05

Table 3. The results of regression analysis for SCCQ factors and EFL learners' GPA

\begin{tabular}{|l|c|c|c|c|c|c|}
\hline Predictors & $\mathbf{R}$ & $\mathbf{R}^{\mathbf{2}}$ & Adjusted $\mathbf{R}^{\mathbf{2}}$ & $\mathbf{F}$ & $\mathbf{P}$ & $\boldsymbol{B}$ \\
\hline$G P A$ & & & & & & \\
\hline Literacy & 0.365 & 0.134 & 0.130 & 41.630 & 0.00 & 0.289 \\
\hline Cultural Competence & 0.383 & 0.146 & 0.140 & 23.084 & 0.04 & 0.137 \\
\hline
\end{tabular}

Table 4. The results of regression analysis for SCCQ factors, parents' educational levels, and EFL learners' GPA

\begin{tabular}{|l|c|c|c|c|c|c|}
\hline Predictors & $\mathbf{R}$ & $\mathbf{R}^{\mathbf{2}}$ & Adjusted $\mathbf{R}^{\mathbf{2}}$ & $\mathbf{F}$ & $\mathbf{P}$ & $\boldsymbol{B}$ \\
\hline$G P A$ & & & & & & \\
\hline Literacy & 0.413 & 0.170 & 0.167 & 48.856 & 0.00 & 0.358 \\
\hline Mother' Education & 0.489 & 0.239 & 0.233 & 37.222 & 0.00 & 0.268 \\
\hline
\end{tabular}

Table 5. Social and Cultural Capital Questionnaire (SCCQ)

\begin{tabular}{|l|l|l|l|l|l|l|}
\hline No. & Statement & SD & D & U & A & SA \\
\hline 1 & I enjoy listening to classical music. & 1 & 2 & 3 & 4 & 5 \\
\hline 2 & I enjoy reading literature. & 1 & 2 & 3 & 4 & 5 \\
\hline 3 & I am a cultured person. & 1 & 2 & 3 & 4 & 5 \\
\hline 4 & I know all famous music composers. & 1 & 2 & 3 & 4 & 5 \\
\hline 5 & I know a lot about literature. & 1 & 2 & 3 & 4 & 5 \\
\hline 6 & I frequently visit museums, theaters, or attend at concerts. & 1 & 2 & 3 & 4 & 5 \\
\hline 7 & I frequently buy/borrow books. & 1 & 2 & 3 & 4 & 5 \\
\hline 8 & I like to attend symphony concerts. & 1 & 2 & 3 & 4 & 5 \\
\hline 9 & I enjoy reading (in general). & 1 & 2 & 3 & 4 & 5 \\
\hline 10 & When a child, my parents regularly encouraged me to read. & 1 & 2 & 3 & 4 & 5 \\
\hline 11 & We have lots of books at home. & 1 & 2 & 3 & 4 & 5 \\
\hline 12 & I used to take art or music classes outside of school. & 1 & 2 & 3 & 4 & 5 \\
\hline 13 & My mother used to get involved in my primary schooling. & 1 & 2 & 3 & 4 & 5 \\
\hline
\end{tabular}




\begin{tabular}{|c|c|c|c|c|c|c|}
\hline 14 & I regularly talk with my parents. & 1 & 2 & 3 & 4 & 5 \\
\hline 15 & I like to get involved in activities designed for young people. & 1 & 2 & 3 & 4 & 5 \\
\hline 16 & My parents usually get involved in my daily activities. & 1 & 2 & 3 & 4 & 5 \\
\hline 17 & I see my siblings weekly. & 1 & 2 & 3 & 4 & 5 \\
\hline 18 & I see my grandparents weekly. & 1 & 2 & 3 & 4 & 5 \\
\hline 19 & My parents used to help me with my homework regularly. & 1 & 2 & 3 & 4 & 5 \\
\hline 20 & I frequently perform activities together with my parents. & 1 & 2 & 3 & 4 & 5 \\
\hline 21 & My mom used to encourage me in my school activities regularly. & 1 & 2 & 3 & 4 & 5 \\
\hline 22 & My mom used to attend school meetings regularly. & 1 & 2 & 3 & 4 & 5 \\
\hline 23 & I feel I have a strong help network for my activities. & 1 & 2 & 3 & 4 & 5 \\
\hline 24 & I see my friends weekly. & 1 & 2 & 3 & 4 & 5 \\
\hline 25 & I have friends with high educational expectations. & 1 & 2 & 3 & 4 & 5 \\
\hline 26 & I had an excellent school with high quality. & 1 & 2 & 3 & 4 & 5 \\
\hline 27 & I am highly proficient in using language. & 1 & 2 & 3 & 4 & 5 \\
\hline 28 & At home, my parents keep track of my progress. & 1 & 2 & 3 & 4 & 5 \\
\hline 29 & My parents know where I am, what I do. & 1 & 2 & 3 & 4 & 5 \\
\hline 30 & My parents used to volunteer for school projects. & 1 & 2 & 3 & 4 & 5 \\
\hline 31 & My parents used to have a regular connection with my school. & 1 & 2 & 3 & 4 & 5 \\
\hline 32 & My parents know parents of my friends. & 1 & 2 & 3 & 4 & 5 \\
\hline 33 & I used to participate in school activities regularly. & 1 & 2 & 3 & 4 & 5 \\
\hline 34 & I used to participate in extracurricular activities. & 1 & 2 & 3 & 4 & 5 \\
\hline 35 & My parents used to monitor my homework regularly. & 1 & 2 & 3 & 4 & 5 \\
\hline 36 & I usually talk about job/education with family. & 1 & 2 & 3 & 4 & 5 \\
\hline 37 & I usually talk about job/education with other adults. & 1 & 2 & 3 & 4 & 5 \\
\hline 38 & My parents used to have a say in school policy. & 1 & 2 & 3 & 4 & 5 \\
\hline 39 & I feel I have strong ties with the community. & 1 & 2 & 3 & 4 & 5 \\
\hline 40 & I feel I have strong ties with my peers. & 1 & 2 & 3 & 4 & 5 \\
\hline 41 & My parents have strong ties with each other. & 1 & 2 & 3 & 4 & 5 \\
\hline 42 & We have an intimate home environment. & 1 & 2 & 3 & 4 & 5 \\
\hline
\end{tabular}

* SD = Strongly Disagree; D = Disagree; $\mathrm{U}$ = Undecided; A = Agree; SA = Strongly Agree 